\title{
COMMERCIAL FINANCING AND THE RELATION BETWEEN SECURED AND UNSECURED CREDITORS IN BANKRUPTCY
}

\author{
Irvin I. LivingstoN* aND John W. Kearns $\dagger$
}

This article deals with problems with which commercial finance companies and banks engaged in secured commercial financing may be confronted in case of the borrower's bankruptcy, in so far as they relate to the protection and enforcement of the collateral. It bears mainly on the practical aspects of the problems, although it necessarily touches on certain of their legal aspects. In consequence, and because of the nature of our treatment, it will not contain that abundance of source-material which the practitioner or the student of legal doctrine customarily expects to find in a law-review article.

\section{The Importance of Constant Mindfulness of Possible Bankruptcy in Carrying on Commerctal Financing Operations}

It is a truism that a security transaction is designed to furnish a lender with a lien on specific property, good against transferees and other creditors. It is also true that the possible advent of the borrower's bankruptcy is a matter to be taken into account at the time the loan is made, both in its bearing on the validity of the security device employed and as a matter of business appraisal of the effect that bankruptcy may have on the value of the security, not only because of the borrower's financial condition but also because of consequent delays and interference with normal methods for the collection of the debt and enforcement of the lien.

These observations have all the dullness of platitude when the subject under discussion is the isolated transaction of a real estate mortgage, a chattel mortgage, or a collateral note secured by pledge of negotiable securities, negotiable warehouse receipts, insurance policies, and the like, since in such cases the lender, after receiving his security, has little or nothing to do but wait for repayment unless default occurs requiring action. However, they take on vitality of particular significance in a treatment of the functionings of lenders in the present-day field of secured

-A.B. 1905, Illinois Wesleyan University; J.D. 1908, University of Chicago Law School. Counsel for Mid-West Conference of Accounts Receivable Companies. Member of the firm of Ryan, Condon \& Livingston of Chicago, and member of the Illinois bar. Author (with Milton P. Kupfer, of the New York bar) of Corn Exchange National Bank $v$. Klauder Revisited: The Aftermath of its Implications, 32 VA. L. REv. 9 I0 (1947), and Supplemental Note, 33 VA. L. REv. I (1947).

† B.S.E. I924, University of Michigan; J.D. I927, Northwestern University Law School. Counsel for the First National Bank of Chicago. Member of Illinois bar. Vice-chairman, Section of Corporation, Banking and Mercantile Law, American Bar Association. 
commercial financing, exemplified mainly in accounts-receivable financing and the several types of inventory financing. ${ }^{1}$

In this field the dealings with each borrower consist of running transactions, frequently from day to day, over extended periods of time. Constant alertness in the handling of the transactions is required to assure both legal and economic protection of the collateral and the lien thereon, as well as to safeguard against the consequences of possible bankruptcy. This is mainly due to the character of the collateral, which is shifting in nature, and to the fact that, in order to fit the loan arrangements to the borrower's commercial needs, the plan of operations contemplates that the borrower be permitted to retain a rather free-handed power to deal with the collateral, particularly to collect pledged accounts and to sell or use pledged inventory in the ordinary course of business, so that the borrower's relations with customers and his normal business operations will not be unduly dislocated.

The expansive proportions to which this field of financing has developed and the extent to which it has found favor as a sound function in the modern business economy are largely attributable to the combination of two elements: one, the facility with which these types of security financing enable the smaller business concern, lacking adequate open bank credit, to obtain added working capital to meet day-today or week-to-week business requirements on a flexible, short-term, and selfliquidating basis, and without undue interruption of its business operations or interference with its customer relations; the other, the fact that, in furtherance of the foregoing object, commercial finance companies, factors, and banks have manifested creativeness in shaping and applying appropriate security devices and techniques for supplying and handling such financing with proper safeguards to protect the lender's rights to the collateral and its proceeds against general creditors.

The conception of the idea of fitting these elements together was one thing; its execution in practice has proved to be quite another matter. The good purpose of developing sound working arrangements, designed to permit the borrower to continue his normal business operations and deal with the collateral as free-handedly as is reasonably possible, has not always been viewed by courts as entirely compatible with the equally good and necessary design to assure the lender a valid lien on the collateral, particularly in the event of bankruptcy. The problem of harmonizing the two designs has taken years of endeavor, involved with trial and error, to progress to the degree of workability it so far has attained; and there are still some aspects

\footnotetext{
${ }^{1}$ Accounts-receivable financing consists of the cashing of accounts receivable arising in the normal conduct of the borrower's business, either by factoring them (i.e., purchasing them and assuming the credit risk in case they turn out to be bad debts), or by lending against them by way of pledge (in which case the credit risk remains on the borrower). Inventory financing consists of lending on the security of shifting inventories of goods, wares, products, raw materials, supplies, or other articles dealt in or manufactured by a business concern, or used in the manufacture of its produrcts, and sometimes may even include goods in process of manufacture. The security devices commonly employed in inventory financing are trust receipts and the pledge of warehouse receipts issued under field warehousing arrangements. In certain states, depending on local laws, the transaction may be by way of statutory factor's liens, or chattel mortgages or conditional-sale contracts with power of resale. Other articles in this symposium treat more fully these various types of transactions.
} 
of the problem yet to be solved. At times the endeavor has had to cope with the rebuffs of adverse judicial decisions and legislation; at other times it has been helped by favorable decisions and legislation.

On the side of favorable legislation, the adoption of the Uniform Warehouse Receipts Act in all the states and the Uniform Trust Receipts Act in about one-half of the states ${ }^{2}$ has been helpful. Encouraging also is the recent adoption in a number of states ${ }^{3}$ of factors' lien acts, under which a lender, called a "factor," by filing a public notice with a designated public official and placing the factor's name on the premises where the merchandise is located, is enabled to acquire a continuing general lien on the borrower's merchandise, including goods in process of manufacture, without taking possession of the merchandise and without the use of fieldwarehousing arrangements. While these acts are not entirely uniform, they generally extend the factor's lien to cover the accounts receivable generated on the borrower's sale of the merchandise. These acts are the most liberal of all in achieving means for establishing a lien good against creditors and at the same time leaving the borrower free to use, sell, or otherwise deal with the collateral in the usual course of business.

On the unfavorable side, to mention the two most important examples, are such outstanding decisions as Benedict v. Ratner ${ }^{4}$ and especially Corn Exchange National Bank and Trust Company v. Klauder, ${ }^{5}$ which interpreted the 1938 Chandler amendment to Section 6oa of the Bankruptcy Act in such a way as to precipitate veritable consternation in the field of security lending. As a result of this decision, a lender on security must make sure that he has fully perfected the transfer of the collateral to such a degree that neither a creditor nor a potential bona fide purchaser from the debtor could thereafter acquire superior rights thereto; otherwise, in case of bankruptcy, the trustee may become entitled to set aside the pledge of the collateral as

${ }^{2}$ Arizona, California, Connecticut, Delaware, Idaho, Illinois, Indiana, Maryland, Massachusetts, Minnesota, Montana, Nevada, New Hampshire, New Jersey, New Mexico, New York, North Dakota, Oregon, Pennsylvania, South Dakota, Utah, Virginia, Washington, and Wyoming.

${ }^{3}$ Alabama, Connecticut, Delaware, Maine, Massachusetts, Minnesota, Missouri, New Hampshire, New Jersey, New York, North Carolina, Ohio, Pennsylvania, Rhode Island, South Carolina, Texas, Vermont, Virginia, and West Virginia.

268 U. S. 353 (1925), holding fraudulent and void under New York law transfers of property as security which reserve to the pledgor dominion to dispose of the property or to apply the proceeds for his own use, the reservation of dominion being inconsistent with effective disposition of title or creation of a lien; e.g., where the pledgor is permitted to use the proceeds of collections or sales as he sees fit without being required to apply them to the repayment of the loan or to replace the collateral with other collatcral.

" 318 U. S. 434 (1943), holding that the trustee in bankruptcy is entitled to recover pledged accounts as preferences if the assignee fails to notify the account-debtors when state law requires notification to perfect title against subsequent bona fide purchasers. The far-reaching effect of this decision, not only as to assignments of accounts but also as to other security transfers, is discussed in other articles in this symposium, and also by Glenn, Mercantile Collateral Law-Present-Day Changes, II Law AND Contemp. Prob. 28I (1945); Hanna, Some Unsolved Problems Under Section 6oa of the Bankruplcy Act, 43 Col. L. Rev. 58 (1943); Ireton, A Proposal to Amend Section 6oa of the Bankruptcy Act, A6 Corp. Reorg. and AM. Bankr. Rev. 257, 258 (1947); Kupfer and Livingston, Corn Exchange National Bank and Trust Co. v. Klauder Revisited: The Aftermath of Its Implications, 32 VA. L. Rev. 910 (I946); Kupfer and Livingston, Corn Exchange National Bank and Trust Co. v. Klauder Revisited: The Aftermath of Its Implications: A Supplemental Note, 33 VA. L. Rev. I (r947). 
a preferential transfer for an antecedent debt, even though in fact the collateral was given for present consideration and not for an antecedent debt. The transaction must be tested by the bona fide purchaser test as well as the creditor test.

Prior to the 1938 amendment, the lender's concern as to bona fide purchasers was only to guard against the debtor's selling and delivering the collateral to an actual purchaser; and this simply as a matter of avoiding loss by having collateral fraudulently sold out from under him, and not as a matter having to do with the question of where the lender might stand in case of the debtor's bankruptcy. Now, under the present Act, the lender must concern himself with the fiction of a hypothetical or imagined purchaser acquiring superior rights-a "Buck Rogers" test, completely unrelated to realities.

What is more, under the present phrasing of Section 60a, if the transaction is not fully perfected against potential purchasers contemporaneously with the making of the loan, the lender is thwarted by another and more devastating fiction: the gap between the passing of the consideration and the time of perfecting the transfer of the collateral operates arbitrarily to turn the transaction into a transfer for an artificial "antecedent" debt, and if it should happen that bankruptcy intervenes before the transfer is perfected, or within four months from the date it is perfected, then the security is expropriated as a preference and given to general creditors in total disregard of the good faith of the transaction and of sound principles and wellestablished, normal commercial practices. A miraculous statute indeed it is that has the magic to transport actualities of earthly business intercourse into a supernatural realm of fictional concepts!

Fortunately, it is now generally realized that the Chandler amendment of Section 60a, as interpreted by the Supreme Court, went too far in the direction of federal legislative interference with commercial practices, and that there is urgent need to correct it. Unless and until Section 6oa is amended, commercial security financing will continue to be unnecessarily hobbled with hazards and problems that should not exist, with the result that it is the business concern in need of such financing which is in many instances deprived of its benefits. To illustrate: except where the possibility of bankruptcy is so unforeseeable as to warrant taking a "calculated risk of exposure," if we may borrow that military term, lending institutions do not feel safe in using trust receipts as a security device because the Uniform Trust Receipts $\mathrm{Act}^{6}$ expressly contemplates that the borrower may sell the goods covered by the receipt in the regular course of his business, free of the lien of the security holder. In similar situation are statutory factors' liens, chattel mortgages on goods in stock, and conditional sale contracts with power of resale, which in some states are good against creditors though not against purchasers.

Faith in the various types of security transactions can be restored only by amendment of Section 6oa to eliminate the purchaser test and to allow a reasonable time, consistent with sound commercial practices, for perfecting liens against creditors.

‘9 U. L. A. 59. 
The urgent necessity for these and other corrections of Section 6oa is more fully dealt with elsewhere in this symposium. We only add the observation that Section $60 \mathrm{a}$ in its present form was framed with single regard to the protection of unsecured creditors; its authors seemed determined at all costs to invalidate liens in those occasional transactions where a real-estate or chattel mortgage is withheld from public record, or pledged property is permitted to remain in the debtor's possession until just before the advent of bankruptcy. In so doing they unwittingly failed to realize that the phraseology employed would work havoc with the functioning of accepted commercial-financing business practices.

Reverting to Benedict v. Ratner, the rule there laid down is that the reservation to the borrower of dominion to dispose of collateral or to apply the proceeds thereof to his own use is inconsistent with and vitiates the lien. The case arose under New York law. It has been followed in some other jurisdictions, ${ }^{7}$ but expressly repudiated in Michigan. ${ }^{8}$ It remains to be seen to what extent it will be followed in other jurisdictions, for local judicial concepts may disagree with its doctrine. The effect of the rule is to require the exercise of vigilance on the part of the lender to insure that transactions with respect to the collateral are such that the borrower is not free to deal with the collateral or its proceeds as he pleases. For example, though it is proper to permit the borrower to collect pledged accounts as agent for the lender, he should be required to account for and pay over the proceeds, unless he has substituted other collateral.

The rule was extended in New York in Lee v. State Bank and Trust Company ${ }^{9}$ to situations where the assignor of accounts is left free to sell returned merchandise as his own property without accounting for it to the assignee. The court took the view that the assignment of the accounts is, in such cases, rendered fraudulent against a trustee in bankruptcy. That this judicial extension of the rule of Benedict v. Ratner is not compatible with orderly commercial intercourse is borne out by the fact that, after the business community had accumulated several years of experience in trying to make the best of it in actual business practice, Section 45 of the Personal Property Law of New York was amended in 1943 to provide expressly that the validity of the assignment of accounts is not affected by the fact that the assignor deals with returned goods as his own property or allows credits or makes adjustments on the assigned accounts, irrespective of whether the assignee has consented

\footnotetext{
${ }^{7}$ Stulz-Sickles Co. v. Fredburn Construction Corp., II4 N. J. Eq. 475, I69 Atl. 27 (I933); Chambers v. Hot Lake Sanatorium, I5I Ore. 20, 45 P. $2 d$ x045 (I935); J. W. Fales Co. v. O. H. Seiple Co., I7I Wash. 640, 19 P. 2d II8 (1933); In re Advance Woodwork Co., 23I Wis. 260, 285 N. W. 747 (I939); Union Trust Co. of Maryland v. Peck, r6 F. 2d 986 (C. C. A. 4th 1927); Manufacturers Finance Co. v. Armstrong, 78 F. $2 d 289$ (C. C. A. $4^{\text {th }}$ 1935); City National Bank of Beaumont v. Zorn, 68 F. $2 d 566$ (C. C. A. 5th 1934).

${ }^{8}$ In re United Fuel \& Supply Co., 250 Mich. 325,230 N. W. I64 (1930). The recent Michigan statute, Mrch. Coxr. Laws $\$ 9563-6$ (Supp. 1945), governing assignment of accounts receivable expressly excludes the operation of the rule of Benedict $v$. Ratner.

${ }^{\circ} 38$ F. 2 d 45, 54 F. 2d 5I8 (C. C. A. 2 d I93I). See also Goldstein v, Rusch, 56 F. 2d Io (C. C. A. 2d 1932), and cf. In re Bernard \& Katz, 38 F. $2 d 40$ (C. C. A. 2 d 1930).
} 
to or acquiesced in such acts of the assignor; also by the fact that at least eight other states have enacted similar statutes. ${ }^{10}$

The rule of Benedict v. Ratner, when first pronounced, was generally viewed as a hard blow to accounts-receivable financing; but we believe we are correct in saying that a growing number of lending institutions engaged in this field have come to the view that, whether or not it is a sound doctrinal rule, at least it has the virtue of prompting lenders to be vigilant for their self-protection in making periodic check-ups on collections, returned merchandise, and the current status of the collateral-or what in the parlance of the industry is known as "policing the account." On the other hand, they are emphatically opposed to any extension of the rule, as in the Lee case, which unnecessarily fetters the assignor in his normal business dealings with his customers and unjustly jeopardizes the assignee's lien, thus working hardships on both parties and operating to enrich unjustly general creditors.

Be that as it may, the fact remains that only in a few states is it settled by judicial decision or statute whether either the rule of Benedict v. Ratner or of the Lee case, or both, are in force. As a result, lending on accounts receivable requires close policing to see to it that the assignor does not have unfettered dominion to treat the proceeds of the accounts or returned merchandise as his own property, or to allow credits or make adjustments on an assigned account, at least without being required promptly to substitute other collateral. Laxity in proper circumspection in these and similar instances presents a danger that in case of bankruptcy the lender may under certain circumstances lose his lien. The basic agreements between the borrower and the lender, when carfully drawn, expressly provide against the exercise of such unfettered dominion by the borrower. But it behooves the lender to use proper vigilance to see to it that such provisions are really performed and not given mere lip-service.

And so it is that experience has demonstrated that lending institutions in daily practice must be mindful of the possible intervention of bankruptcy, even though only a small percentage of business concerns accommodated with security financing ever go into bankruptcy. In order to be safe, the lender at almost every turn finds himself asking the question whether he has acquired a valid lien that will prevail over a potential trustee in bankruptcy, and whether he has done something or failed to take action in some respect that will jeopardize the lien. And even if his course of dealing has been such as not to render his lien vulnerable, he still has to face bothersome problems if bankruptcy does ensue. That is the topic of the discussion which follows.

\footnotetext{
${ }^{10}$ Mo. Laws 194I, c. 18, $\$ 3347.5$; N. C. Laws 1945, c. I96, $\$ \$ 8-84$; Texas Acts 1945, c. 293, $\$ 8$; Conn. Laws 1943 Supp., c. 235a, \$880 h; Maine Pub. Laws 1945 c. 100, \$170-B; Mass. Laws 1945, c. I4I, \$5; Minn. Laws I945, c. 503, \$5; N. H. Laws 1945, c. 263-A, \$5.
} 
II

\section{Procedural Problems and Creditor Conflicts in Bankruptcy and} Reorganization Proceedings

Promptly on the institution of proceedings in bankruptcy, the secured lending institution is met with a complexity of obstacles interfering with its normal rights and remedies with respect to the collateral. The entry of general or special restraining orders, or the fact that the collateral may be in the actual or technical possession of the bankruptcy court, operates to stay enforcement of the lien, even though the validity of the lien is unassailable. The security holder finds itself in a position where it must now deal with new parties not of its choosing-a receiver or trustee, the attorney for the receiver or trustee, attorneys for a creditors' committee or intervening creditors, as well as the judge or referee-and promptly there arises real concern as to what the effect of all this will be on the value of the collateral.

As to assigned accounts, what shall be done regarding their collection? Shall the account debtors be notified to pay direct to the lender? Self-protection ordinarily dictates an affirmative answer, but that course may be promptly thwarted by service of a restraining order which must first be vacated; or it may be, depending on the circumstances of the particular case, that it is better to let the estate collect. Certainly it is foolhardy for both the assignee and the representatives of the bankrupt estate to go after the account debtors, for then the debtors will hesitate to pay either.

Fortunately, by discussing and treating with the problem realistically and in a businesslike manner, the parties generally reach an agreement rather promptly. Whether the agreement reached is to allow the assignee to collect or to allow the estate to collect, the order of court can be drawn adequately to protect the rights of both sides. Usually it has been found better policy for the assignee to collect, especially in straight bankruptcy proceedings. At times, when the receiver or trustee has taken an adamant position against that course, lending institutions have, unfortunately, been impelled to sense that such position has been prompted by a desire to "make a showing" to the court which will be reflected on the question of allowances of fees.

As to pledged inventories, what shall be done about "moving" the inventory? Here again similar questions arise. If the goods are physically in the adverse possession of the pledgee, or are held by a bailee or a warehouseman for the pledgee, the pledgee is entitled to have the restraining order vacated. But to avoid protracted dispute and possible depreciation of the goods, the situation calls for early agreement as to their disposal on a businesslike basis, particularly if the goods are perishable or likely to depreciate in value because of delay. Whether the goods are to be sold by the pledgee or by the court's officer, the order of court can be drawn to protect the rights of both sides in the proceeds.

Frequently today, business financial catastrophies first descend upon the courts through the route of proceedings under Chapter X or Chapter XI of the Chandler 
Act, providing respectively for corporate reorganizations and debtor arrangements. These chapters, intended as vitamin-fortified prescriptions for the relief of ailing businesses, have largely replaced the old-fashioned equity receivership-fashioned to hold creditors at bay while the affairs of the debtor are being rearranged, whether by change of management, shift in operations, or by rescaling or extension of debts, to the end that it might be launched again on its commercial career with some possibility of success.

When such a proceeding is instituted by or against a debtor, creditors holding security generally find that their right to enforcement of their lien is likely to be delayed longer than in straight bankruptcy proceedings, since the purpose is to rehabilitate and to forestall liquidation. The first thing to be determined is whether there is any possibility of resuscitating the patient. If so, then a proceeding under Chapter X or Chapter XI is a proper vehicle. If not, the sooner the patient is switched to the ward that provides for liquidation in straight bankruptcy proceedings, the better it will be for all creditors, secured and unsecured.

At this point secured and unsecured creditors have interests in common. While the unsecured creditor in a certain sense may have more at risk than his secured companion, neither wants to see the assets of the estate, whether encumbered or free, jeopardized by delays or the prospect of continuing losses. If the circumstances indicate that rehabilitation has real prospects of accomplishment, realistic businessmen should be able to come to agreement upon a plan with the minimum of delay, except in occasional borderline cases, and even there a compromise of some type will usually be found better than extensive litigation. But if rehabilitation is doubtful, remote, or unduly delayed, the secured creditor, as well as the unsecured, ought to move to have the case turned into a straight bankruptcy proceeding.

Most concerns that actually reach the bankruptcy stage unfortunately are found to have an asset position such that, after the satisfaction of prior tax liens, the estate may not adequately provide for the secured creditors, much less the general creditors. The result too frequently is that the lending institution which has been providing the debtor with security financing is faced with the likelihood of any one or more of a number of lines of attack, even though its secured position is legally valid.

Litigation attacking the lien may fall in either of two general categories: first, a summary proceeding instituted in the bankruptcy proceeding itself by the trustee, in which he asserts that he is in possession of the property upon which a lien is asserted; ${ }^{11}$ or second, a plenary proceeding, in which the receiver or trustee, not having possession of the property, is required to resort to a regular lawsuit or chancery proceedings instituted by him in some other court for the purpose of compelling the secured lender to surrender his security, unless the security holder submits to the jurisdiction of the bankruptcy court. If the trustee has possession of the property, the security holder has no choice but to submit to summary jurisdiction. 1940).

1152 STAT. 854 (1938), ir U. S. C. $\$ 46$ (1940); Collier on BAnkruptcy $\$ 23.05$ et seq. (14th cl. 
In the past it has been felt that it was disadvantageous for the secured lender to subject himself to the summary jurisdiction of the bankruptcy court, where the prevailing atmosphere was thought likely be one of favoring general creditors at the expense of the secured creditor. This has at least in part been due to the fact that referees in bankruptcy were paid on a more or less contingent basis, dependent upon the dollar value of the assets distributed by them. ${ }^{12}$ Fortunately, under the recent amendment to the act governing the compensation of referees in bankruptcy, ${ }^{13}$ they are no longer dependent upon the amounts distributed by them. They are paid on a regular basis which eliminates any improper incentive, even unrecognized by them, to increase the amount of the general estate for distribution to general creditors. Besides this, there seems to be a growing feeling on the part of secured creditors that it is better to try out issues before federal judges or referees, who by experience have a better knowledge and understanding of bankruptcy questions than have the judges of state courts. On the other hand, the secured creditor is often hesitant to submit to summary jurisdiction, realizing that an effort to mix extraneous issues into the controversy is more easily accomplished in an informal proceeding in bankruptcy than it is in a formal litigation in another forum.

It should also be borne in mind that summary jurisdiction may be conferred by consent, express or inferred, and one entering into a stipulation or moving to dissolve a restraining order or taking other affirmative steps in the proceeding should move cautiously unless he has decided to let the bankruptcy court settle the controversy. ${ }^{14}$

In all situations where dispute results one should continuously keep in mind the factor of his own financial position. Many interesting legal problems can be resolved only by protracted litigation, with the result that both parties to the contest may lose substantially from the expense and delays involved. The impact of the federal income tax upon either or both parties to a compromise is also frequently an exceedingly important factor that is sometimes overlooked.

It is not within the purview of this article to discuss the numerous other conflicts between secured and unsecured creditors which may arise upon bankruptcy, such as the substantive law involved in contests over the validity of liens or preferential or fraudulent transfers. Suffice it here to point out that, during the time the debtor is a solvent and going concern, the dangers of loss to the security lender, in the absence of outright, active fraud on the part of the debtor, are not likely to be as acute as they may be when bankruptcy intervenes. The reason, of course, is that on the advent or imminence of bankruptcy both the borrower and the lender are deprived of that full degree of freedom of action, which was theirs prior thereto, to protect the lender's position.

Granted that on the occurrence of bankruptcy a certain-amount of delay and interruption of the normal rights of security holders is inevitable, it is altogether

1230 STaT. 556 (I898), II U. S. C. $\$ 68$ (1940).

${ }^{13} 60$ STAT. 326 (1946), II U. S. C. A. $\$ 68$ (Supp. 1947).

"Collier on Bankruptcy $\$ 23.08$ (14th ed. 1940). 
unfortunate that their problems are further aggravated by the fact that the proceedings by which they are brought face to face with general creditors are at times infected with manifestations of unwarranted antagonism. So long as the facts of a particular case warrant, lending institutions have, as they should have, due regard to the propriety of pursuit of legitimate methods to contest lien claims that are defective, to upset preferential or fraudulent transfers, and to protect fairly the rights of general creditors in other respects. But at times, where the secured position is not open to question, the persistence of attacks gives strong indication that the purpose is to tire the security holders into conceding reductions of their claims, or to discourage the filing of unsecured claims for any deficiency after realizing on the security.

Such antagonism between classes of creditors has no legitimate place in the administration of bankrupt estates. It is inimical to and out of keeping with the modern business economy, which is so largely dependent on both secured and unsecured credit. During the time that the business concern has been prospering, trade creditors and security lenders are able to deal with the customer in harmony. Their respective methods of extending credit are complementary to one another despite their differences in situation and their techniques for extending credit. Bankruptcy of the customer need not, and ought not, cause discord and animosities between them if both classes of creditors will but realize that fair and businesslike practices are important for the orderly administration of bankrupt estates, no less than for everyday commercial intercourse.

\section{III}

\section{Financing Business Operations During Bankruptcy Procerdings}

There has been a growing practice in bankruptcy proceedings for receivers, trustees, and debtors in possession to borrow from commercial financing institutions funds needed to continue the operation of the debtor's business, the purpose being to preserve its going-concern value, whether in proceedings to rehabilitate the debtor under Chapter $\mathrm{X}$ or Chapter $\mathrm{XI}$ or in liquidation proceedings leading to the sale of the business as a going concern.

The growth of this practice seems to have gathered impetus after the successive I933, 1935, and 1938 amendments to the Bankruptcy Act, which introduced the so-called debtor-relief sections. ${ }^{15}$ Prior to these amendments, the Act contained no express provision conferring on bankruptcy courts power to authorize receivers or trustees to borrow money or to issue certificates of indebtedness. However, the authority was considered implied in Section 2a(5) of the Act, which empowers bankruptcy courts to "authorize the business of bankrupts to be conducted for

${ }^{25}$ Sec. $77 c$ (3), 47 Stat. I 474 (1933), 49 Stat. 91 I (1935), II U. S. C. \$205c (3) (1940); c. X, SII6 (2), 52 Stat. 885 (1938), II U. S. C. \$5I6(2) (1940); c. XI, \$344, 52 STAT, 909 (I938), II U. S. C. $\$ 744$ (I940); c. XII, $\$ 446,52$ STAT. 920 (I938), II U. S. C. $\$ 846$ (I940). 
limited periods by receivers, the marshals, or trustees, if necessary in the best interests of the estates. ...."16

The general provisions of the present Act are still silent on the subject; but in each of the present debtor-relief sections we find provisions, substantially alike, to the effect that, upon cause shown, receivers, trustees, and debtors in possession may be authorized "to issue certificates of indebtedness for cash, property or other consideration approved by the judge, upon such terms and conditions and with such security and priority in payment over existing obligations, secured or unsecured, as in the particular case may be equitable." These are extremely broad powers. Not only can the indebtedness represented by the certificates be treated as an expense of administration, giving the certificates priority in payment over general creditors, but it can be secured by specific assets, and even given priority over existing secured claims if that is found to be equitable in the particular case.

The argument might be made that the failure to incorporate a like provision in the general bankruptcy sections implies that Congress did not intend that the court should have these powers in ordinary bankruptcies. That argument lacks merit. It would not be proper to infer a legislative intent to override the existing judgemade law on the subject, particularly in the face of Section 2 of the Act. Section $2 a$ enumerates several express grants of power to courts of bankruptcy in respect of which they are vested with "such jurisdiction at law and equity as will enable them to exercise original jurisdiction"; 17 and Section $2 \mathrm{~b}$ expressly provides that "nothing in this section contained shall be construed to deprive a court of bankruptcy of any power it would possess were certain specific powers not herein enumerated."18

Thus, it is safe to say, the implied power still exists in ordinary bankruptcies to authorize certificates of indebtedness payable as expenses of administration in priority over general creditors. The further equitable power to grant security on specific assets can also be safely inferred. In passing on problems arising in the administration of bankrupt estates, courts of bankruptcy are essentially courts of equity in the sense that they apply the principles of equitable jurisprudence in exercising jurisdiction conferred by the Act. ${ }^{19}$ On equitable principles, the court can borrow, so to speak, from the express provisions found in the debtor-relief sections of the Act as to authorizing certificates with security, and priority in payment, at least as against general creditors.

Certain precautions must be kept in mind in undertaking loans to receivers, trustees, or debtors in possession. First and foremost, the loans should be authorized by an appropriate order duly entered in the proceedings. Receivers, though officers

${ }^{10} 52$ Stat. 842 (1938), II U. S. C. \$IIa(5) (r940). In re Restein, x62 Fed. 986 (E. D. Pa. 1908); In re Erie Lumber Co., 150 Fed. 817 (S. D. Ga. 1906); In re C. M. Burkhalter \& Co., 182 Fed. 353 (N. D. Ala. I910); In re John W. Farley \& Co., 227 Fed. $37^{8}$ (C. C. A. $7^{\text {th }}$ 1915).

${ }^{27} 52$ STAT. 842 (1938), II U. S. C. §ira (1940).

1052 Stat. 842 (1938), II U. S. C. \$I Ib (I940).

10 Pepper v. Litton, 308 U. S. 295 (r939). 
of the court, have no inherent power to borrow money without court order. ${ }^{20}$ The same principle applies to trustees and debtors in possession, for they stand in a position analogous to that of receivers. ${ }^{21}$ Likewise, and axiomatically, the pledging of accounts or other security requires express court authority.22 The sections of the Act relating to the issuance of certificates of indebtedness in proceedings under Section 77 and Chapter $\mathrm{X}^{23}$ expressly provide for the entry of the order by the judge, so that an order entered by a referee in such cases would not be sufficient; and the same rule would seem to apply in ordinary bankruptcy proceedings. In Chapter XI and XII proceedings, ${ }^{24}$ the order may be entered by either the judge or a referee. The applicable sections of the Act as to giving of notice and findings of cause shown for entering the order should be followed carefully.

After the order is entered, it is important that the lender make sure that the loan transactions themselves conform to the order, since the order is the source of, and necessarily operates as a limitation on, the power and authority of the receiver, trustee, or debtor in possession to borrow or to give security. Failure to be circumspect in this may prove costly.

For example, an order authorizing the debtor in possession to continue the business and to buy and sell on credit has been held insufficient to authorize the borrowing of money on assigned accounts. ${ }^{25}$

In another case the court authorized $\$ 15,000$ of receiver's certificates to provide funds to pay wages and to complete the manufacture of unfinished merchandise. The receiver could not find a buyer for the certificates. Then a later order was entered authorizing $\$ 5,000$ of certificates secured by the equity in accounts already assigned to a factor, and also authorizing the receiver to borrow 75 per cent of its current accounts receivable as they arose, the remaining 25 per cent to be security for the $\$ 5,000$ certificates. The first $\$ 5,000$ advanced on the certificate was repaid. Later the factor advanced another $\$ 5,000$ upon a certificate purporting to be issued under the first order. It was held that the borrowing on this second certificate was unauthorized, since the first order under which it purported to be issued had been superseded by the later court order. ${ }^{26}$ On a second appeal of the same case, it was also held that the order authorizing the factor to advance 75 per cent of the assigned

${ }^{20}$ Union Trust Co. v. Illinois Midland Ry., Ir7 U. S. 434 (1886); Chicago Deposit Vault Co. v. MeNulta, 153 U. S. 554 (1894); cf. In re C. M. Burkhalter \& Co., 182 Fed. 353 (N. D. Ala. 1910), to the effect that a receiver authorized to conduct the business has implicd power to purchase on credit and to borrow necessary funds without express order of court. To same effect, see In re J. C. Grocndyke Co., 131 F. 2d 573 (C. C. A. 7 th 1942).

21 In re Avorn Dress Co., 78 F. 2d 681 (C. C. A. 2d 1935).

22 Byrnes v. Missouri National Bank, 7 F. $2 d 978$ (C. C. A. $2 d$ 1935); In re Avorn Drcss Co., 78 F. 2d 68r, 79 F. 2d 337 (C. C. A. 2d I935); Standard Capital Corp. v. Saper, r15 F. 2d 383 (C. C. A. 2d I940); In re American Cooler Co., 125 F. $2 d 496$ (C. C. A. 2d 1942).

${ }^{23}$ Scc. $77 c(3), 47$ Stat. I 474 (1933), 49 Stat. 911 (1935), I1 U. S. C. $\$ 205 c(3)$ (1940); c. X, \$116(2), 52 STAT. 885 (1938), i U. S. C. \$516(2) (1940).

${ }^{24}$ C. XI, $\$ 344,52$ STAT. 909 (1938), II U. S. C. $\$ 744$ (1940); c. XII, $\$ 446,52$ STAT. 920 (1938), II U. S. C. $\$ 846$ (1940).

${ }^{25}$ In re Avorn Dress Co., supra note 22.

${ }^{20}$ Standard Capital Corp. v. Saper, stupra note 22. 
accounts was not sufficient to authorize the advancement of Ioo per cent, and it was not in the power of the factor to waive the 75 per cent limit. ${ }^{27}$

In each of these cases the lender contended that, although the loans were not authorized, they should nevertheless be treated as expenses of administration entitled to priority in payment over general creditors; but it was held that such equitable relief can be allowed only in exceptional cases. In the opinion in one of these decisions, the Circuit Court of Appeals for the Second Circuit pronounced certain standards to guide the courts in determining under what circumstances such equitable relief may be granted, but cautioned that each case must stand on its own feet. The court observed: "We should emphasize that this equitable power must be cautiously exercised, and that only a foolhardy lender will attempt to make it serve as a substitute for proper authorization."28

This discussion thus far has in the main dealt with loans on certificates of indebtedness. What about adapting the customary types of running agreements for financing accounts receivable and for inventory loans without using certificates of indebtedness? Has the bankruptcy court power to authorize such loans? No reported case has come to our attention where this question was squarely in issue. The point was touched on in the American Cooler ${ }^{29}$ case, where the court held that the authority granted the receiver to borrow up to 75 per cent of the face value of assigned accounts did not authorize roo per cent borrowing; but no issue seems to have been raised as to the power to authorize the loan. Yet in actual practice there have been many unreported precedents in which receivers, trustees, and debtors in possession have been authorized to continue in force existing financing agreements, or to make new ones, thus by-passing the more cumbersome method of requiring certificates of indebtedness.

While the method of borrowing on certificates of indebtedness may have certain virtues-in that its orthodoxy has gathered both judicial and statutory sanction and for that reason some practitioners have been impelled to advise lenders to adapt accounts-receivable and inventory financing to that method where feasible-it would be unrealistic and reactionary for courts to take the narrow view that it is the only method that can be authorized. Going business concerns have discovered that the modern methods of providing themselves with financing as needed from day to day on a flexible and self-liquidating or revolving basis, by pledging their receivables as they arise or by pledging their constantly shifting inventories, do have definite advantages over borrowing fixed sums for a fixed period of time. No sound reason appears why receivers, trustees, and debtors in possession should be denied the advantages of these methods in continuing business operations of debtors in bankruptcy. On the contrary, the power to authorize borrowing by these modern methods can and should be implied under the equitable powers of bankruptcy courts as readily as has been the power to authorize the issuance of certificates of indebtedness.

${ }^{27}$ In re American Cooler Co., supra note:22. .. $\quad{ }^{28}$ Id. at 497:

20 Silpra note 22. 
The order of court authorizing such financing (whether or not certificates of indebtedness are employed) can, and for the proper protection of the lender should, provide that the advances to be made shall be entitled not only to the security of the specific accounts or inventory to be pledged, but also to priority in payment as a cost of administration over existing general creditors, and also, if it is deemed proper in the particular case, ahead of indebtedness and expenses incurred in the operation of the business by the receiver, trustee, or debtor in possession. Such protection, it is submitted, is entirely fair and proper since the lender's funds are to be used to defray operational charges, such as payrolls, accruing taxes or rents, purchases of supplies, and other necessary expenses. For additional protection, the order should expressly provide that the advances shall have priority in payment over any future certificates of indebtedness which may be issued to any other person, or it should prohibit the issuance of future certificates unless the current issue is paid.

Unless experienced lending institutions, equipped to finance receivables and inventories, are prepared to lend funds to operate the debtor's business pending reorganization or until sale, fullest use will not be made of the power to authorize certificates of indebtedness, except perhaps in railroad and public-utility reorganization proceedings. The use of the orthodox type of certificates in railroad and other public-utility receiverships is one thing. It is quite another in bankruptcy proceedings of private business concerns. In the former, it is rather customary to make the certificates a first and prior lien on all the properties, ahead of existing bond issues or other liens. This is justified because railroads and utilities are quasi-public corporations serving the public interest and convenience, and the bondholders in accepting a mortgage on the property do so with knowledge of the legal condition that, for the purpose of keeping the enterprise a going concern, receiver's certificates may be issued, supplanting the mortgage lien, to supply funds to pay the expenses of continuing operations and preserving the security of the mortgage. ${ }^{30}$ To accomplish such displacement of existing liens, a hearing before the court after due notice to the lien-holders is required. The hearing is frequently protracted. Then, generally, the certificates are offered for public sale. All this takes time, but the daily revenues of the railroad or utility are generally sufficient to carry on operations in the meantime. The intricacies and magnitude of the problems to be dealt with and the complexity of the procedure combine to make railroad and utility reorganizations long-drawn-out proceedings in which the element of the time required to process marketable certificates seems to be of secondary importance.

There are obvious differences in the case of private corporations. In the general run of bankruptcies and receiverships of private concerns, even if we assume that the court has power under proper circumstances to displace existing liens by firstlien certificates, ${ }^{31}$ the time required to authorize and place certificates of the ortho-

${ }^{30}$ Miltenberger v. Logansport Ry., ro6 U. S. 286 (1882).

${ }^{31}$ See In re Prima Co., 88 F. 2 d 785 (C. C. A. 7 th 1937 ), holding that such power exists in banknuptcy proceedings of private corporations under the express powers granted in old $\$ 77 \mathrm{~B}$ of the Bankruptcy Act (on which the present provisions in the Chandler amendment are modeled). The court, however, stated that the issuance of certificates having priority over existing liens calls for careful, cautious, and considerate action, and the case must be a strong one, unless the lienors consent. 
dox type and the likelihood of delaying appeals make the procedure too cumbersome and time-consuming to serve the immediate needs for ready funds required for operations. Here and there a party in interest or other lender may be willing to buy that type of certificate, or even a certificate that does not go to the extent of displacing existing liens. But such certificates lack general appeal, for, even though their ultimate payment as an expense of administration may be well assured, there is no certainty as to when they will be paid. Surely lending institutions engaged in accounts-receivable financing, being accustomed to self-liquidating secured loans, have little or no interest in them. But they will be interested if they are given an unqualified lien upon specific free current assets on a self-liquidating basis, and are reasonably assured that their loans have priority in payment. Their familiarity and experience with that kind of lending makes them the logical and ready lender.

This problem of financing the operations of a business during the pendency of bankruptcy has real potentialities for good. Lending institutions and the bankruptcy fraternity can give it vitality, provided it is approached and dealt with on bases consonant with sound business practices assuring adequate security and priority in payment. 